\title{
CULTURALIZATION STRATEGIES FOR THE DEVELOPMENT OF MAYAN CULTURE IN GUATEMALA
}

\author{
Francisco Javier Herrera Del Cid \\ Department of International Trade, \\ Chonbuk National University, South Korea \\ Ji Young Jeong \\ Department of International Trade, \\ Chonbuk National University, South Korea
}

\section{http://dx.doi.org/10.26739/2573-5616-2018-3-2-9}

\begin{abstract}
: this paper will provide an assessment of the potential culturalization and commercialization of the Maya's traditions and culture around the world. Through this study it is intended to verify and show that Guatemala could be increase aggregate welfare for tourist sector in the long run. Guatemala is a country characterized by its great cultural wealth, where the traditions of the different peoples are part of the Guatemalan identity. Unfortunately, nowadays, there is not yet a cultural exposition of that identity that will represent the characteristics of the Mayan community. As we know, tourism sector is an important source of income for a state. The natural resources represent a clear advantage for the economy of a country. The purpose of this research is to present an alternative of income through the development of strategies for cultural tourism in the country, this proposal not only will point out asustainable tourism but also the participation of the rural community with the purpose of its integration and progress.
\end{abstract}

Key words: culturalization, Tourism, Mayas, Economic Strategies, Guatemala. JEL Clasification: F18, R11, J15, M31

\section{Introduction}

Sustainable tourism development is a clear and forceful articulating axis, taking into account the absolute and comparative advantages that the country has against the world.

For Guatemala, it represents a real option for economic and social development, demonstrating its capacity to contribute effectively to the generation of decent employment and productive occupations, to the protection of the environment and cultural heritage, as well as to the strengthening of national identity.

Tourism in Guatemala has grown gradually, is an attractive destination because of the abundant and varied natural beauty and its long beaches of white sand and dark sand, coral reefs, abundant flora and fauna, and archaeological beauties, its colonial history, plus its entire culture expressed in their customs and traditional foods. 
There is a strong interest of the international community for archaeological sites like the city of Tikal was built and occupied in a period where the Mayan culture had its most literal and artistic expression, was ruled by a dynasty of 16 kings, the Mayas of Tikal built many temples, a ball park, altars and steles in high and low relief.

Based on this, the Mayan culturalization analysis seeks to solve the unknown about how big the potential tourist is benefit for the Republic of Guatemala. This motivates the develop of a plan for create a center for the teaching of Mayan-Guatemalan culture that will help to facilitate its recognition at the national and international levels, thus achieving greater local socio-economic development.

\section{Literature Review}

Tourism is widely believed to be the most rapidly growing global industry, and the World Tourism Organization predicts international tourism will grow at approximately 4\% per year through the year 2010 (World Tourism Organization 1996). In definitional discussions, there is often an underlying assumption that tourism to small rural communities will be planned and that planning with environmental and community development goals in mind will help ensure their achievement. This assumption of planning is problematic, as the level of choice exercised by host communities in becoming a destination is questionable with tourism in general, and particularly in developing countries (Cater 1994a). Based as it often is on visits to rural towns and villages in remote and undeveloped areas (Wild 1994).

In order to find a methodology for this research, it can be found vast studies of tourism's economic impact based on benchmarking cases, which show the strategies applied to the tourism sector. The following is based upon review of some benchmarking studies gathered by the authors on the economic impact of tourism published in English. Benchmarking is a tool for improving performance. Edith Cowan University defines benchmarking as a continuous and systematic process of comparing products, services, processes and outcomes with other organizations or exemplars, for the purpose of improving outcomes by identifying, adapting and implementing best practice approaches (Edith Cowan University, 2011).

Comparisons may be made against individual benchmarking partners or groups. Benchmarking is a tool to assist organizations identify processes they need to change to be able to achieve specific strategic goals and objectives (Hacker \& Kleiner, 2000). Benchmarking is the formal and structured process of searching for those practices which lead to excellent performance, the observation and exchange of information about those practices, the adoption of those practices to meet the needs of one's own 
organization, and their implementation (Meade, 1998). Benchmarking is focused on improvement so it complements other improvement initiatives.

Here are some more useful definitions that will help to give a value support in this research, seeking to understand in a better way the terms using in this research:

\section{Tourism:}

In 1980, The Manila Declaration on World Tourism defined tourism is an important, even vital, source of income for many regions and countries. Its importance was recognized in the Manila Declaration on World Tourism of 1980 as "an activity essential to the life of nations because of its direct effects on the social, cultural, educational, and economic sectors of national societies and on their international relations.

In 1941, Hunziker and Kraft defined tourism as "the sum of the phenomena and relationships arising from the travel and stay of nonresidents, insofar as they do not lead to permanent residence and are not connected with any earning activity.

In 1994, the United Nations identified three forms of tourism in its Recommendations on Tourism Statistics:

- Domestic tourism, involving residents of the given country traveling only within this country.

- Inbound tourism, involving non-residents traveling in the given country.

- Outbound tourism, involving residents traveling in another country.

\section{Culture:}

In 1974, the anthropologist E.B. Taylor defined culture as "that complex whole which includes knowledge, belief, art, morals, law, custom and any other capabilities and habits acquired by man as a member of society."

In 2015, James, Paul with Magee, Liam; Scerri, Andy and Steger, Manfred B. Defined culture as" A social domain that emphasizes the practices, discourses and material expressions, which, over time, express the continuities and discontinuities of social meaning of a life held in common."

\section{Cultural Tourism:}

In 2009, OECD (Organization for Economic Co-operation and Development) defined cultural tourism as "the subset of tourism concerned with a country or region's culture, specifically the lifestyle of the people in those geographical areas, the history of those people, their art, architecture, religion(s), and other elements that helped shape their way of life. Cultural tourism includes tourism in urban areas, particularly historic or large cities and their cultural facilities such as museums and theaters. It can also include tourism in rural areas showcasing the traditions of indigenous cultural communities (i.e. festivals, rituals), and their values and lifestyle, as well as niches like industrial tourism and creative tourism. 
In 1996, Richards, G. defined cultural tourism as 'the movement of persons to cultural attractions away from their normal place of residence, with the intention to gather new information and experiences to satisfy their cultural needs'.

\section{Culturalization:}

Oxford Univiversity Press 2017 defined culturalization as "the process of adapting to one's cultural environment; the acquisition of values and behavior compatible with the society of which one is a member. Also: adaptation to or imposition of the culture of another nation or people."

In 2011, Kate Edwars defined culturalizaton as "The process by which content is further adapted for a broader diverse audience. However, unlike localization which is usually perceived as a production step that takes place later in the development cycle."

\section{Guatemalan Current Tourism Economics Facts}

\subsection{Guatemala Current Economic Overview}

Guatemala is the most populous country in Central America with a GDP per capita roughly half the average for Latin America and the Caribbean. The agricultural sector accounts for $13.6 \%$ of GDP and $31 \%$ of the labor force; key agricultural exports include sugar, coffee, bananas, and vegetables.

Guatemalais the top remittance recipient in Central Americaas aresult of Guatemala's large expatriate community in the US. These inflows are a primary source of foreign income, equivalent to over one-half of the country's exports or one-tenth of its GDP.

The Dominican Republic-Central America Free Trade Agreement (CAFTA-DR) entered into force in July 2006, spurring increased investment and diversification of exports, with the largest increases in ethanol and non-traditional agricultural exports.

\section{<Table 1> Guatemala Principal Economic Indicators}

\begin{tabular}{|l|r|c|}
\hline \multicolumn{1}{|c|}{ Economic Indicator } & \multicolumn{1}{c|}{ Value } & World Rank \\
\hline Courrency & Quetzal (GTQ) & - \\
\hline GDP (purchasing power parity) & $\$ 140.2$ billion & $\# 78$ \\
\hline GDP (official exchange rate) & $\$ 68.39$ billion & $\# 79$ \\
\hline GDP - real growth rate & $3.50 \%$ & $\# 76$ \\
\hline GDP - per capital (current price) & $\$ 7,900$ & $\# 151$ \\
\hline Gross National Saving & $12.9 \%$ of GDP & $\# 108$ \\
\hline Imports & $\$ 16.76$ billion & $\# 80$ \\
\hline Exports & $\$ 11.43$ billion & $\# 82$ \\
\hline Population & 16.34 million & $\# 71$ \\
\hline Population below poverty line & $59.30 \%$ & $\# 11$ \\
\hline Labor force & 6.316 million & $\# 87$ \\
\hline Unemployment rate & $2.90 \%$ & $\# 21$ \\
\hline Taxes and other revenues & $11.5 \%$ of GDP & $\# 155$ \\
\hline
\end{tabular}

Source: http://www.indexmundi.com/guatemala/economy_profile.html 


\section{<Figure 1> Guatemala GDP Composition}

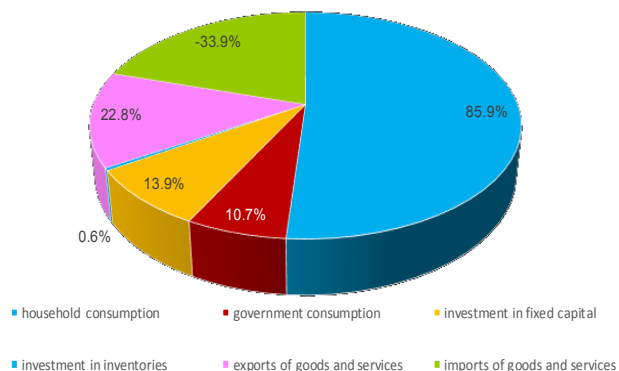

Source: http://www.indexmundi.com/guatemala/economy_profile.html

Guatemala has been one of the strongest economic performers in Latin America in recent years, with a GDP growth rate of 3.0 percent since 2012, and 4.1 percent in 2015. Economic projections for 2016 show that the country will grow by 3.6 percent.

This Central American country has made significant progress in achieving macroeconomic and democratic stability after a 36-year civil war. Since the signing of the Peace Accords in 1996, the country has improved its access to international markets through several trade agreements.

According to World Bank estimates, if Guatemala grows at a rate of 5.0 percent in each of the next few years and that growth does not come at the expense of the poor, the marginal impact on poverty and equity will be significant. The poverty rate would fall by an additional 1 percentage point by the end of 2016, enabling an additional 160,000 people to escape poverty.

\section{$<$ Figure 2> Guatemala GDP by Sector}
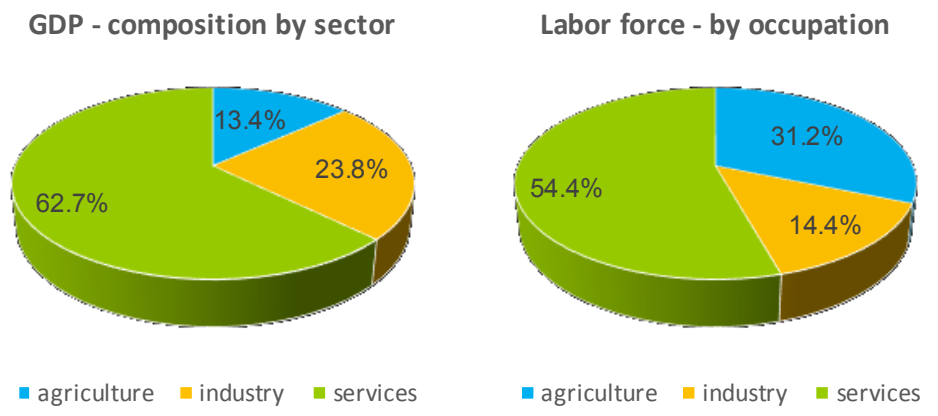

Source: http://www.indexmundi.com/guatemala/economy_profile.html

\begin{tabular}{|c|l|}
\hline Agriculture & sugarcane, corn, bananas, coffee, beans, cardamom; cattle, sheep, pigs, chickens. \\
\hline Industries & sugar, textiles and clothing, furniture, chemicals, petroleum, metals, rubber. \\
\hline Services & transportation, education, tourism, commerce. \\
\hline
\end{tabular}




\subsection{Economic Frame in the Tourism Sector}

\section{GDP, Direct Contribution:}

The direct contribution of Travel and Tourism to GDP was USD 1.98 billion (3.4\% of total GDP) in 2015 this raised $2.9 \%$.

\section{GDP, Direct Total Contribution:}

The total contribution of Travel and Tourism to GDP was USD 5.21 billion (8.8\% of total GDP) in 2015 this raised 3.2\%.

\section{Employment, Direct Contribution:}

In 2014 Travel and Tourism directly supported 183,000 jobs (2.9\% of total employment), in 2015 this raised 2.9\%.

\section{Employment, Direct Total Contribution:}

In 2014, the total contribution of Travel and Tourism to employment, including jobs indirectly supported by the industry was $7.9 \%$ of total employment (489,000 jobs). This raised 2.6\% in 2015 to 501,500 jobs.

\section{Visitor Exports:}

Visitor exports generated USD 1.6 billions ( $12 \%$ of the total exports in 2014. This forecast to grew up $2.4 \%$ in the last 2015 .

\section{Investment:}

Travel and Tourism investment in 2014 was USD 6.88 millions, or $8.2 \%$ of total investment. This grew up $6.3 \%$ in the last 2015 .

The direct contribution of Travel \& Tourism to GDP in 2014 was USD $1.98 \mathrm{bn}$ (3.4\% of GDP). This raised $2.9 \%$ to USD 2.04bn in 2015. This primarily reflects the economic activity generated by industries such as hotels, travel agents, airlines and other passenger transportation services.

- Leisure travel spending (inbound and domestic) generated 65.8\% of direct Travel \& Tourism GDP in 2014 (USD 2.47 bn) compared with $34.2 \%$ for business travel spending (USD 1.29bn).

- Leisure travel spending grew up 2.4\% in 2015 to USD 2.53bn.

- Business travel spending is expected to grew by $4.0 \%$ in 2015 to USD $1.34 \mathrm{bn}$ and raised $2.7 \%$.

\section{<Figure 3> Travel \& Tourism's Contribution to Guatemala GDP.}

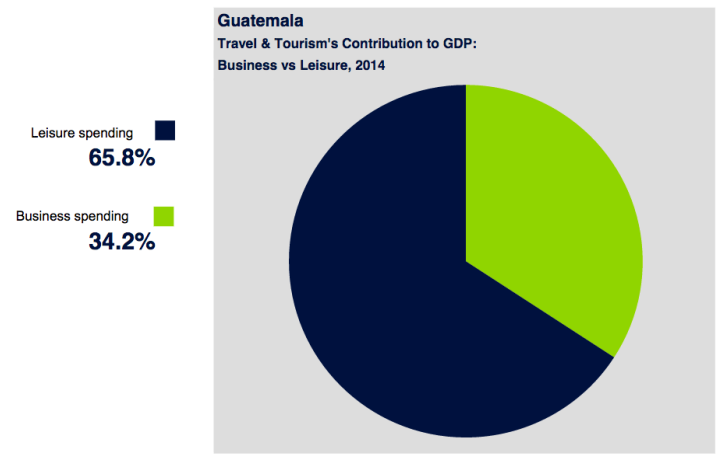

Source: World Travel \& Tourism Council. 
The direct contribution of Travel \& Tourism to GDP reflects the 'internal' spending on Travel \& Tourism (total spending within a particular country on Travel \& Tourism by residents and non-residents for business and leisure purposes) as well as government 'individual' spending - spending by government on Travel \& Tourism services directly linked to visitors, such as cultural (museums) or recreational (national parks).

\section{<Table 2> Arrival of Non-Resident Visitors by Type of Traveler}

\begin{tabular}{|c|c|c|c|c|c|}
\hline \multirow{2}{*}{ Month } & \multirow{2}{*}{ Tourists } & \multicolumn{3}{|c|}{ Excursionists } & \multirow{2}{*}{ Total } \\
\hline & & Cruisers & $\begin{array}{l}\text { Visitors } \\
\text { of the day }\end{array}$ & Total & \\
\hline Total & $1,585,115$ & 103,712 & 228,091 & 331,803 & $1,916,918$ \\
\hline January & 134,256 & 7,789 & 18,822 & 26,611 & 160,867 \\
\hline February & 118,404 & 10,714 & 16,618 & 27,332 & 145,736 \\
\hline March & 168,739 & 13,101 & 33,635 & 46,736 & 215,475 \\
\hline April & 109,759 & 11,111 & 17,692 & 28,803 & 138,562 \\
\hline May & 106,831 & 8,734 & 23,371 & 32,105 & 138,936 \\
\hline June & 121,969 & 638 & 12,072 & 12,710 & 134,679 \\
\hline July & 145,980 & 844 & 16,315 & 17,159 & 163,139 \\
\hline August & 142,078 & - & 14,556 & 14,556 & 156,634 \\
\hline September & 97,965 & 2,287 & 22,754 & 25,041 & 123,006 \\
\hline October & 132,930 & 11,068 & 16,202 & 27,270 & 160,200 \\
\hline November & 131,323 & 15,418 & 18,662 & 34,080 & 165,403 \\
\hline December & 174,881 & 22,008 & 17,392 & 39,400 & 214,281 \\
\hline
\end{tabular}

Source: www.inguat.gob.gt/inteligencia-de-mercados.php

\section{<Figure 4 > Arrival of Non-Resident Visitors by Type of Traveler}

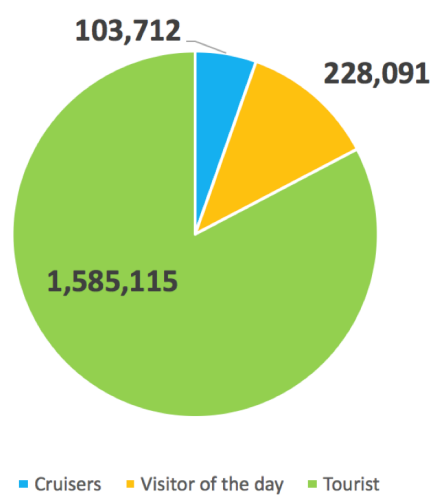

Source: www.inguat.gob.gt/inteligencia-de-mercados.php 
<Table 3> Arrivals of Non-Resident Visitors by Country of Residence

\begin{tabular}{|c|c|c|c|c|c|}
\hline \multirow{2}{*}{ Country } & \multirow{2}{*}{$\begin{array}{c}\text { November } \\
2016\end{array}$} & \multicolumn{4}{|c|}{ December 2016} \\
\hline & & Tourist & Excursionist & & \\
\hline TOTALS & 149,985 & 174,881 & 17,392 & 192,273 & $100 \%$ \\
\hline North America & 35,332 & 39,632 & 1,309 & 40,941 & $21 \%$ \\
\hline United States / Canada & 27,249 & 33,265 & 963 & 34,228 & $18 \%$ \\
\hline Mexico & 8,083 & 6,367 & 346 & 6,713 & $3 \%$ \\
\hline Central America & 89,984 & 117,270 & 15,965 & 133,235 & $69 \%$ \\
\hline Belize & 566 & 538 & 163 & 701 & $0 \%$ \\
\hline El Salvador & 72,686 & 101,618 & 14,777 & 116,395 & $61 \%$ \\
\hline Honduras & 6,997 & 5,965 & 991 & 6,956 & $4 \%$ \\
\hline Rest of Central America & 9,735 & 9,149 & 34 & 9,183 & $5 \%$ \\
\hline South America & 7,597 & 4,756 & 12 & 4,768 & $2 \%$ \\
\hline Europe & 12,814 & 9,396 & 102 & 9,498 & $5 \%$ \\
\hline Rest of the World & 4,258 & 3,827 & 4 & 3,831 & $2 \%$ \\
\hline
\end{tabular}

Source: www.inguat.gob.gt/inteligencia-de-mercados.php

<Figure 5> Arrivals of Non-Resident Visitors by Country of Residence

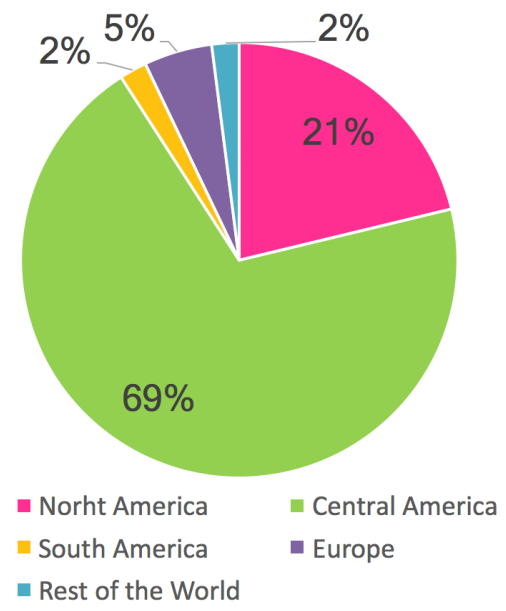

Source: www.inguat.gob.gt/inteligencia-de-mercados.php

\section{Cultural Tourism Demand in Guatemala}

\subsection{The Cultural Tourist Profile}

Destination Guatemala, "alma de la tierra", the soul of the earth. The largely mountainous country is located in Central America bordered by the Pacific Ocean in south, and it has a narrow coastline on the Caribbean Sea. Border countries are Belize, El Salvador, Honduras, and Mexico. The mountainous areas of Guatemala are home to more than 30 volcanoes, many of them still active. 
The Maya civilization flourished in Guatemala and surrounding regions during the first millennium A.D. After almost three centuries as a Spanish colony, Guatemala won its independence in 1821.

With an area of $109,000 \mathrm{~km}^{2}(42,085 \mathrm{sq}$. mi.), the country is about the size of Bulgaria, or slightly larger than the US state of Kentucky. Guatemala has a population of 15,8 million (in 2014). Capital and largest city is Guatemala (City), it is the most populous city in Central America with about 1 million people. Spoken languages are Spanish (official) and about twenty Mayan languages especially in rural areas.

Tourism became one of the main drivers of the economy, an industry that reported more than $\$ 1.8$ billion in 2008. Guatemala received about two million tourists annually.

In recent years it has led to the visit of many cruise ships that touch important seaports in Guatemala, leading to more tourists visiting the country.

In its territory there are fascinating Mayan archaeological sites (Tikal in the Peten, Quirigua in Izabal, Iximche in Tecpan Chimaltenango, and in the City of Guatemala). Destinations of natural beauty as Lake Atitlan and Semuc Champey. As historical tourism is the colonial city of Antigua Guatemala, which is recognized by UNESCO Cultural Heritage.

Guatemala is very popular for its archaeological sites, pre-Hispanic cities as well as tourist-religious centers like Basilica of Esqui pulas and City of Esqui pulas and also the beautiful beaches on the Pacific and Atlantic coasts of Guatemala. Other tourist destinations are the National Parks and others Protected Areas such as the Maya Biosphere Reserve.

Mundo Maya Organization (MMO) with information on Mayan culture and the Organization's aim to achieve social development and sustainable tourism within the Mayan regions.

\subsubsection{Guatemala Ethnicities}

Official 2014 statistics indicate that approximately $60.2 \%$ of the population is "non-indigenous", referring to the mestizo population and the people of European origin. These people are called Ladino in Guatemala.

Approximately $39.8 \%$ of the population is indigenous and consist of 23 Maya groups and one non-Maya group. These are divided as follows: (K'iche 9.1\%, 8.4\% Kaqchikel, Mam 7.9\%, 6.3\% Q'eqchi', other Maya peoples $8.6 \%, 0.2 \%$ indigenous non-Maya) hey live all over the country, especially in the highlands.

Other racial groups include numbers of Afro-Guatemalans, AfroMestizos, and Garifuna of mixed African and indigenous Caribbean origins who live in the country's eastern end. Some Garifunas live mainly in Livingston, San Vicente and Puerto Barrios. They descend mainly from the Arawaks and Belizean Creoles. 
There are thousands of Arab Guatemalans descending from; Palestine, Syria, Jordan, Iraq, and other Arab countries who reside in Guatemala City. Some belong to Christian Churches while others to Islamic Mosques. There are also thousands of Jews residing in Guatemala. They are immigrants from Germany and Eastern Europe that arrived in the 19th century. Many immigrated during World War II. There are approximately 9,000 Jews living in Guatemala today. Most live in Guatemala City, Quezaltenango and San Marcos. Today, the Jewish community in Guatemala is made up of Orthodox Jews, Sephardi, Eastern European and German Jews.

The 1893 Guatemalan Census reported that 481,945 persons, or $35.3 \%$ of the population, were Ladinos (defined as both whites and people of European and Indian descent), and 882,733 persons, or $64.7 \%$ of the population, were Natives.

\section{European Guatemalans}

Approximately, $18.5 \%$ of the population is considered White or Caucasian, accounts for more than 3 million of the population. Most are of German and Spanish descent, but there is a considerable number of people of Italian, Belgian, French, British, Swiss, Finnish, Russian and Hungarian descent.

The departments of Zacapa and Chiquimula are half or predominantly of Spanish descent, with castizos, the white populations make up more than $80 \%$ in these departments, where many European immigrants arrived, mainly the 19th and 20th centuries. In Guatemala City there is a significant amount of minority descendants of Europeans (35-40\%), and other minorities with more than $20 \%$ in Coban, Carlos V and Xelaju.

\section{Mestizo Guatemalans}

Guatemalan Mestizos are people of mixed European and indigenous ancestry. The Mestizo population is heavily populated in urban areas of the country (the national capital and departmental capitals).

Historically, the Mestizo population in the Kingdom of Guatemala at the time of Independence amounted to nearly 600,000 Indians, 300,000 Castes (mostly Mestizos and a lesser number of Mulattos), and 45,000 Criollos or Spanish, with a very small number of Spaniards.

\section{Indigenous Guatemalans}

The Amerindian populations in Guatemala include the K'iche' 9.1\%, Kaqchikel 8.4\%, Mam 7.9\% and Q'eqchi 6.3\%. 8.6\% belongs to other Maya groups, $0.4 \%$ belong to non-Maya indigenous peoples. The whole indigenous community in Guatemala is about $40.5 \%$ of the population.

\subsection{Why to invest in Guatemala?}

Guatemala is a country with an enormous quantity of natural resources, full of contrasts between a great historic past and the development of its 
cosmopolitan capital city, which becomes highly attractive to tourists from all over the world.

- Strategic geographic location in the heart of the Mesoamerican region.

- Legal framework that encourages investment and government support for the tourism industry.

- Tourists in Guatemala seek to travel to different places within the country during their visits, with an average length of stay of around 7.5 days, according to the United Nations Conference on Trade and Development (UNCTAD).

- Invest in Guatemala offers direct support to foreign investors looking for opportunities for investment.

\section{<Figure 6> Number of Tourists and Foreign Income from Tourism}

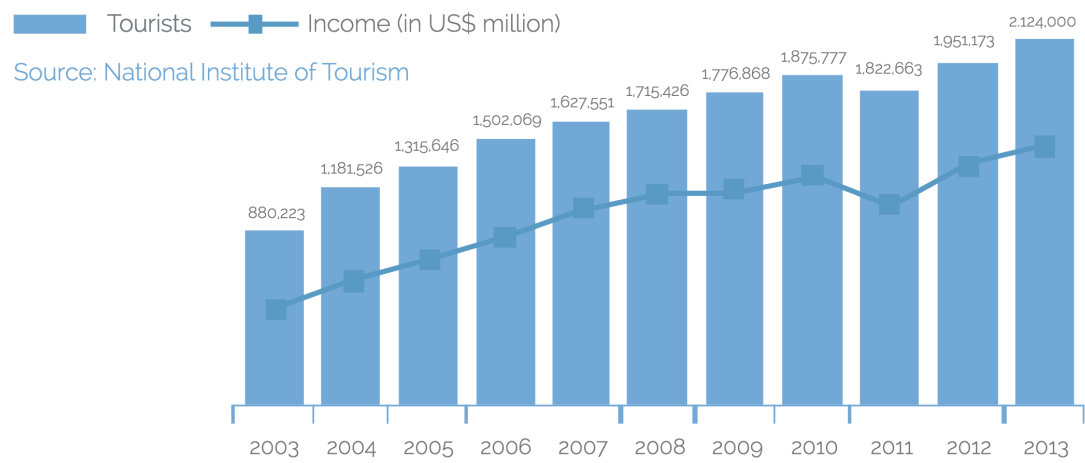

Source: (Investing in Guatemala, 2018)

Guatemala has been recognized as a unique destination for Mayan and Colonial history cultural tourism. 52\% of the country's tourism market comes from Central America and 32\% from North America. Specifically analyzing the North American visitors, $68.5 \%$ of them came from the United States. Other important amount of visitors came from Europe (8.9\%), mainly from England (16.4\%), Spain (15.1\%), France (13.5\%) and Germany (12.6\%).

\subsubsection{Airports}

La Aurora International Airport, located in Guatemala City, is considered as one of the most modern airports in the Central American region, with the capacity to receive 4 million passengers per year. Nowadays, this airport operates more than 160 weekly flights and direct connections to six cities in the U.S., Mexico, Central America, Peru and Spain.

This airport has also been recognized, due to its new and modern facilities, as Category A. $507 \mathrm{Km}$ (315 mi) away from Guatemala City, in 
the department of Peten, is the second international airport of the country, "Mundo Maya International Airport". This airport is mainly visited by tourists with interest is to visit the ancient Mayan city of Tikal.

The country also has regional airports in other growing cities like Quetzaltenango, Huehuetenango, Retalhuleu, San Marcos, Coatepeque, Puerto San Jose and Puerto Barrios.

Also, Guatemala has been pursuing to increase its air traffic; currently the country has managed to get new flight frequencies on airlines like Avianca, Copa, Aeromexico, United Airlines and American Airlines; establish new routes to Tapachula, Mexico and Bogota, Colombia.

As well as attracted Aerolaneas Sula (Honduran airline) to offer flights to and from Guatemala. In addition, there are recent incorporations with other companies like AirCanada, JetBlue, Volaris, Interjet (FRS), Transaero, GOL and Wamos Air.

\subsubsection{Hotel Occupancy}

While Guatemala has presented an annual growth rate of around 3.6\% in the accommodation capacity; the touristic demand has presented a higher average annual growth rate; demonstrating that the hotel/accommodation supply in Guatemala does not fully satisfy the demand, and it's a clear opportunity for both national and foreign investors to develop this sector.

Considering the current hotel supply and tourists demand for accommodation, as well as the diversity of products and destinations offered in Guatemala (with more than 10 unique destinations) allows visitors to extend their stay to an average of 7 days; there is clearly an opportunity in the country to invest in the tourism industry.

The 3 departments of Guatemala with the largest number of accommodation facilities are: Guatemala City, Peten and Solola. Nevertheless, these existent hotel facilities are not enough to cover the demand in peak seasons (like Holy Week and Christmas-New Year's). Also, other departments like Retalhuleu has only 67 lodging establishments, which currently do not meet the high demand of tourists, knowing that the department is visited both for its attractiveness in natural resources and because it houses the largest theme parks in Central America (Xetulul and Xocomil), capable of receiving up to 12 thousand people simultaneously. 


\section{<Table 4> Hotel Rooms Occupancy}

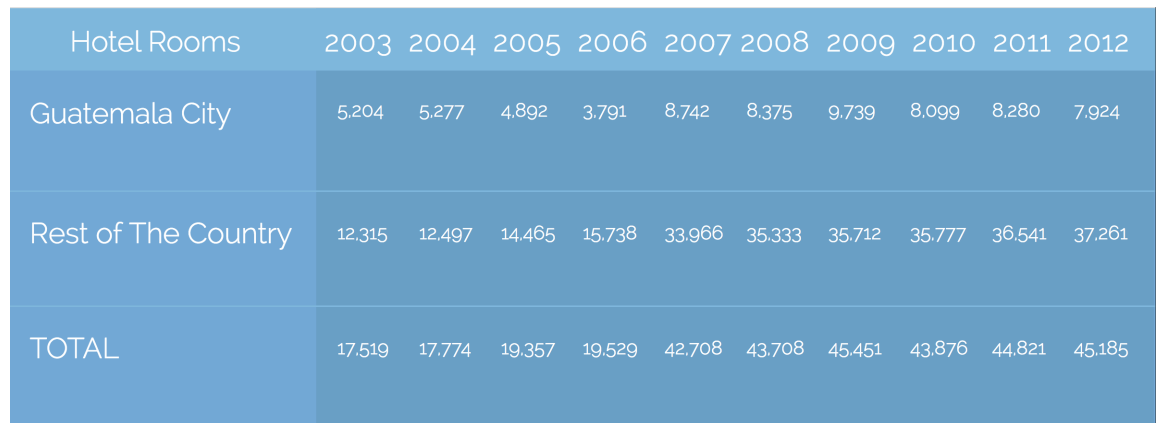

Source: www.investinguatemala.org

\subsubsection{Cruise Ship Tourism}

The Guatemalan Tourism Institute (INGUAT) established what is now called the "Mesoamerican Route", a new cruise route at a regional level, and includes the countries of Costa Rica, Nicaragua, El Salvador, Guatemala, Chiapas and Huatulco, Mexico, which in 2014 initiated with two Cruises from Azamara Club Cruises, Royal Caribbean Cruises Ltd. For this new cruise season, the country has achieved 4 new cruise lines: Saga, Great Lakes Cruise, Carnival Cruises Noble Caledonia (largest cruise line in the world).

The arrival of cruise ships to the country increased from 48 cruises in the 2014-2015 season to 72 cruises for the season and 74 in 2015-2016. The cruise company Royal Caribbean Cruise Line increased its moorings in the country from 6 cruises during the 2014-2015

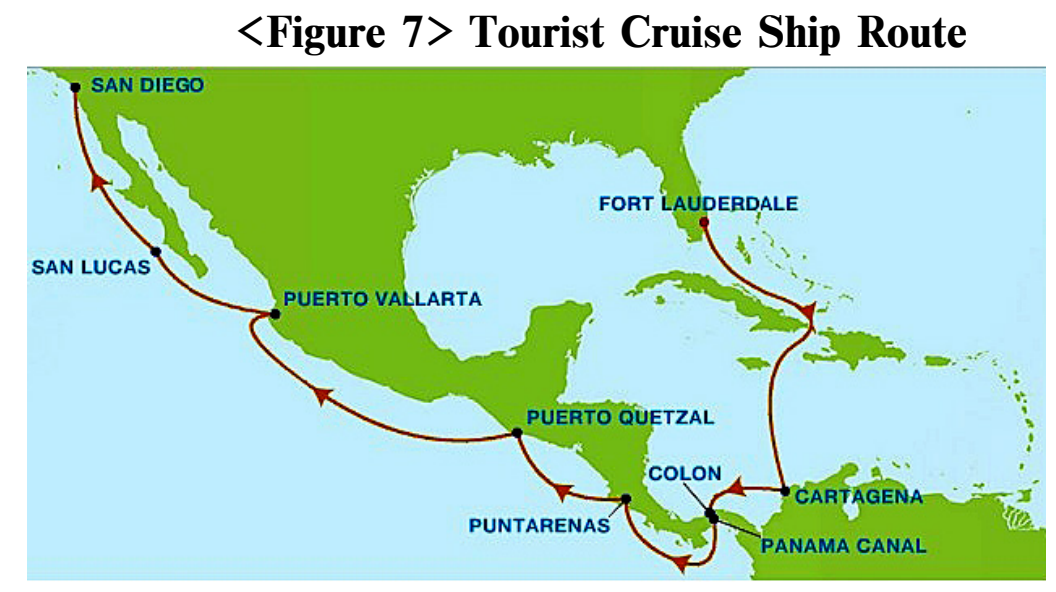

Source: www.investinguatemala.org 


\section{Strategies for Develop a Maya's Cultural Tourism Experience in Guatemala}

Cultural tourism focuses on the natural beauty, people, customs and heritage of a particular area along with its indigenous cultures. Countries around the world with pristine, unique or grand natural and cultural attributes are spotlighted in a 'sustainable' manner in order to preserve these attributes and at the same time generate revenue for the destination area.

The strategies should promote recycling, energy efficiency, and water re-use. On the other hand, should avoid negative impact that can damage or destroy the integrity or character of the natural or cultural environment.

\subsection{Development of Strategies}

\subsubsection{Training and Participation of the Local Communities}

Employment in protected areas should be developed, training must be conducted in order to employ local residents for various personnel positions such as tour guide, gate keeper or fee collector. Private enterprise is necessary to support the demand for tourist services. Management and entrepreneurial training occurs so that local residents may own and operate trekking and guiding services or lodging establishments.Leadership training to facilitate self-governance and self-management of local community programs is provided so that cultural tourism becomes a community organized and controlled industry. General conservation and environmental education programs are instituted into schools as part of community organizations. Programs include recycling or park sponsored conservation lessons. Basic tourism theory is provided so that there is an understanding of the impacts of tourism, positive aspects of tourism and sustainable development doctrines.

Mayan tourism as a concept focuses on travel for education of the tourists and also on the indigenous culture as an attraction. There is a lack of effective interpretation and educational programming at sites which should be a primary focus of ecotourism development. Local residents are the target for the training and education programs. The change that would occur to the indigenous culture because of such training and education is at cross purposes to preservation of culture.

\subsubsection{Partnership Between Public and Private Sector}

Developing PPPs as a collaborative form of governance recognizes the interdependence of the various parties in developing tourism, especially at the early stages.Partnerships can focus on aparticular task and bring together those organizations with the skills and knowledge necessary for its completion. In many situations, as we demonstrate in this report, PPPs 
play a critical role in the development of tourism. A government cannot usually develop tourism by itself, as it does not operate businesses, while the private sector may need help with regulations, access to resources, and funding.

This is often true in regional areas where the government may control the natural attractions and the local people do not have funds for development or have the skills to develop tourism. We can summarize the main points of this strategy in:

- Government support enabling certification to be free of charge to businesses.

- High technical and ethical standards, making it one of the best in the world.

- The establishment of an independent accreditation body with wide representation.

- Create management initiatives.

- Use of marketing practices.

\subsubsection{Culturalization, Strengthening of the Mayan Cultural Identity}

The relationship between culture, heritage, the environment and tourism has received a great amount of attention throughout the world. Yet rarely have individuals or organizations representing these special interests worked together on a local, regional, or national basis to define their common interests and discover ways in which they can

develop a strong and mutually beneficial working relationship that conserves natural, cultural, and human resources. Today, it is not distance but culture and heritage that separates the people of the world. How do we create stronger links between historic sites and monuments, indigenous people in the host community, and those individuals seeking a quality cultural tourism experience? How do we improve the life of the two hundred and fifty million indigenous people in the world through ecotourism? Individuals interested in cultural tourism tours and projects are generally professionals with a higher degree of education than the average traveler.

Those people choosing to participate in adventure travel are usually younger than travelers interested in cultural travel. Most have an interest in the natural resources and culture of the area they are visiting. Most of them also want to see many species of wildlife and at the same time understand wildlife in the context of the people who inhabit the area they are visiting.

One approach is through the integration of cultural tourism with cultural heritage tourism (travel directed toward experiencing local traditions, arts, and heritage while respecting the host community and its surrounding 
environment). Cultural heritage tourism is an important link that should be part of all ecotourism products and tour packages. People travel to see how other people live, to experience their neighborhoods, and to understand the natural environments that define their existence. Culture and heritage sums up a community's beliefs and values-shared behavior acquired as the result of living within a group and a defined geographic area. To develop ecotourism without considering local culture is to take the humanity out of cultural tourism.

\section{Conclusions}

If the strategies before mentioned are applied in the Guatemalan economy the results wil be these:

- Local communities will work together bringing social and economic benefit.

- These strategies will improve the overall environmental management of Guatemala.

- The quantity and variety of cultural tourism activities will increase.

- Local population and private sector will get benefits, such as income growth, education, and cultural exchange.

- Creation of new businesses.

- Creation of full-time and part-time jobs directly and indirectly related to the tourism sector.

- Locals and tourists will get knowledge about ecotourism and protection of natural areas.

- Commitment between communities and the government, working in partnership.

It is expected that cultural tourism becomes an alternative of the development in the country, bringing positive outcomes and showing the importance of diversify the income source.

The Guatemalan economy should grow after the implementation of these strategies, and the local areas and communities where the implementation of these projects be conducted should generate more Jobs, create new industries and business derived by tourism.

However, the limitations of this study are based on the lack of data, which does not make possible to show the feasibility of the strategies and the application into the Guatemalan economy. 


\section{References}

Arnegger, J., Woltering, M., \& Job, H. (2010). Toward a product-based typology for nature-based tourism: a conceptual framework. Journal of Sustainable Tourism; Vol. 18; No. 7.

Burns, P., Palmer, C., Lester, J., \& Bibbings, N. (2015). Tourism and Visual Culture Methods and Cases. En Tourism and Visual Culture, Vol. 2. University of Brighton.

Conference-Board. (2011). Retrieved from The Conference Board Economics. [Online] Available: : https://www.conference-board.org/pdf_free/economics/TED.pdf

Index Mundi. (2017). Retrieved from Guatemala?s Economy Profile [Online] Available: http://www.indexmundi.com/guatemala/economy_profile.html

INGUAT. (2016). Travel \& Tourism, Economic Impact in Guatemala 2016. Guatemala City, Guatemala.

Instituto Guatemalteco de Turismo. (2017). Retrieved from INGUAT-Inteligencia de Mercados: www.inguat.gob.gt/inteligencia-de-mercados.php

Investing in Guatemala. (2018). Retrieved from http://www.investinguatemala.org/ Ivanovic, M. (2008). Cultural Tourism. Mercury Crescent, Welton 7780, Cape Town, South Africa.

Kamisnki, J., Benson, A., \& Arnold, D. (2013). Routhledge Studies in Contemporary Geographies of Leisure, Tourism and Mobility. En Contemporary Issues in Cultural Heritage Tourism, Vol. 42. University of Brighton.

Reisinger, Y., \& Moufakkir, O. (2015). Cultural issues in tourism, hospitality and leisure in the Arab/Muslim world. En International Journal of Culture, Tourism and Hospitality Research, Volume 9, Issue 1. Emerald Group Publishing Limited.

Song, H., \& Witt, S. (2000). Tourism Demand Modelling and Forecasting: Modern Econometric Approaches. United Kingdom: Elsevier Science.

Standard \& Poor?s. (2012). Retrieved from Ratings and Definitions [Online] Available: http://www.standardandpoors.com/ratings/definitions-and-faqs/en/eu

World Travel \& Tourism Council. (2017). Retrieved from WTTC [Online] Available: https://www.wttc.org/ 